\title{
ANALISIS KARAKTERISTIK MATERIAL MENGGUNAKAN PARALEL PLATE SAMPLE HOLDER PADA BROADBAND DIELEKTRIK SPEKTROMETER
}

\author{
Oleh \\ Era Madona
}

Staf Pengajar Teknik Elektro Politeknik Negeri Padang

\begin{abstract}
Dielectric spektrometer is used to measure complex dielectric function of material which depends on the frequency. The measured in domain frequency learn about movement of dipole's molecule and electric conductions in capasitor charging process. The most familiar measuring method of frequency area is parallel plat capasitor and four electrode system (V. Raicu et al, 1994). In this method, the measuring material is placed betwen two electroda in parallel place. This configuration produce a capasitor system which is possible to measure the complex impedance of the capasitor sample.

In this research, measuring and analyzing the material characterization are done in high frequence to design circuit and development of many material. Based on this reason, this reseach uses dielectric spectrometer system with HP Impedance Analyzer $4191^{a} \mathrm{RF}$ and frequency 1-1000 MHz. Spectrometer can be used on complex permittivity to measure the compact material. The measuring result can be implemented in high frequency range using phenomenological relaxation model. However, the accuracy of such predictions would need careful further study.
\end{abstract}

Keyword : Dielectric spektrometer, parallel plate capasitor, complex permittivity

\section{PENDAHULUIAN}

Dielektrik adalah material yang mempunyai tahanan yang besar terhadap aliran listrik. Bahan ini banyak digunakan dalam dunia industri seperti pada pembuatan peralatan elektronika, switch optoelektronik, industri PCB, aplikasi mikrowave untuk radar, baterai cell dan lain-lain. Dibidang biomedik, bahan dielektrik banyak digunakan untuk menentukan karakteristik organ dan jaringan, kadar air dalam badan dan medical imaging dengan menggunakan gelombang mikro. Aplikasi lain dari bahan dieletrik juga dapat dilihat pada bidang pertanian, yaitu untuk penentuan kualitas produksi pertanian seperti kadar kelembaban pada gabah dan minyak sayur.

Untuk menentukan data dielektrik yang akurat secara efisien diperlukan peralatan khusus yang dikenal dengan dielectric spektrometer. Alat ini dapat mengukur dielectric properties dari suatu material dengan lebar frekuensi tertentu. Salah satu lebar frekuensi yang dapat digunakan adalah dari $10^{-6} \mathrm{~Hz}$ sampai $10^{12} \mathrm{~Hz}$. Pemberian frekuensi ini akan dapat menggambarkan struktur dan sifat-sifat molekul dari material yang diukur seperti pergerakan molekul. 
Dielectric spektrometer digunakan untuk mengukur complex dielectric function dari sebuah material dan ketergantungannya terhadap frekuensi. Pengukuran yang dilakukan pada domain frekuensi mempelajari pergerakan dipole molekul dan konduksi elektrik pada proses pengisian sebuah kapasitor. Metoda pengukuran pada daerah frekuensi yang banyak digunakan adalah paralel plate capasitor dan sistem empat elektroda (V. Raicu et al, 1994). Pada metoda ini material yang akan diukur diletakkan diantara dua elektroda yang diletakkan secara paralel sehingga membentuk kapasitor dalam sebuah sistem sehingga dapat dilakukan pengukuran complex impedance dari sampel kapasitor yang digunakan. Sangat banyak perusahaan yang bergerak dibidang instrumentasi mengaplikasikan metoda ini pada sistem mereka, sebagai contoh Solarton 1260 gain phases impedance dan Novocontrol HP4991, HP4291, HP4191 RF Impedance Analyzer.

Disamping metoda konfigurasi sample holder dengan menggunakan parallel plate capasitor, metoda lain yang dapat digunakan adalah konfigurasi coaxial. Pada metoda ini, material sampel dihubungkan pada kabel coaxial yang dihubungkan pada sisi luar dan terminal intinya untuk dilakukan pengukuran. Hasil pengukuran yang dilakukan akan membantu dalam pengembangan berbagai macam bahan yang digunakan dalam bahan transmisi.

Pada penelitian ini, akan dilakukan pengukuran dan analisis sifatsifat bahan dielektrik pada frekuensi tinggi yang sangat penting dilakukan untuk perancangan rangkaian dan pengembangan berbagai macam bahan. Berdasarkan hal ini, penelitian dilakukan untuk merancang sebuah sistem dielektrik spektrometer menggunakan HP Impedance Analyzer $4191^{\mathrm{a}}$ RF dengan frekuensi $1-1000 \mathrm{MHz}$. Spektrometer dapat digunakan untuk pengukuran complex permitivity pada bahan-bahan padat.

\section{Tujuan Penelitian}

Pada penelitian ini dilakukan penganalisaan karakteristik material dielektrik sample pada frekuensi 1 $1000 \mathrm{MHz}$ menggunakan paralel plate sample holder pada broadband dielektrik spektrometer (HP Impedance Analyzer $4191^{\mathrm{a}} \mathrm{RF}$ ).

\section{Perumusan Masalah}

Bagaimana menganalisa karakteristik material dielektrik sample pada frekuensi $1-1000 \mathrm{MHz}$ menggunakan paralel plate sample holder pada broadband dielektrik spektrometer (HP Impedance Analyzer $4191^{a} \mathrm{RF}$ ).

\section{Tinjauan Teoritik}

\section{Bahan Dielektrik}

Bahan dielektrik (k) ekivalen dengan relative permitivitas $\left(\varepsilon_{\mathrm{r}}\right)$ atau absolute permitivitas $(\varepsilon)$ relatif terhadap permitivitas ruang hampa $\left(\varepsilon_{0}\right)$. Bagian riil dari permitivitas $\left(\varepsilon_{\mathrm{r}^{\prime}}\right)$ menunjukkan seberapa banyak energy dari medan listrik eksternal yang dapat disimpan dalam material. Sedangkan bagian imajinir dari permitivitas $\left(\varepsilon_{\mathrm{r}}\right.$ ") atau loss factor menunjukkan tingkat dissipasi atau kerugian material terhadap medan listrik eksternal.

Bagian imajinir dari permitivitas mempunyai nilai yang lebih besar dari nol dan biasanya jauh lebih kecil dibandingkan dengan bagian rill dari permitivitas $\left(\varepsilon_{\mathrm{r}^{\prime}}\right)$. Loss factor berhubungan dengan pengaruh dari dielektrik loss dan konduktivitas 
Hubungan antara kapasitansi bahan dielektrik dan konstanta dielektrik dari bahan tersebut dapat dilihat pada persamaan 1 sampai 3 .

$$
\begin{aligned}
& C_{\square}=\frac{A}{\bar{z}} \\
& C=C_{0} k^{\prime} \\
& k^{\prime}=\varepsilon^{\prime}{ }_{r}=\frac{C}{C_{0}}
\end{aligned}
$$

Dimana :

$\mathrm{C}=$ kapasitansi dengan dielektrik

$\mathrm{C}_{0}=$ kapasitansi tanpa dielektrik

$\mathrm{k}^{\prime}=\varepsilon_{\mathrm{r}}^{\prime}=$ bagian riil dielektrik konstanta atau permitivitas

$\mathrm{A}=$ luas penampang kapasitor plate

$\mathrm{t}=$ jarak antara kapasitor plate

\section{Parallel Plate}

Metode parallel plate dapat dengan mudah digunakan lebih cocok untuk bahan sample berbentuk padat. Sample holder ini terdiri dari elektroda bagian atas dan elektroda bagian bawah. Bahan sample diletakkan diantara kedua elektroda ini hingga menyentuhnya. Karena susunan bahan sample yang seperti ini, maka sample dalam bentuk cair dan semi padat tidak memungkinkan untuk digunakan pada metode ini.

Kedua elektroda pada sample holder ini dihubungkan pada sumber electromagnetic dengan tujuan untuk memberikan medan listrik eksternal pada bahan sample seperti tampak pada gambar 1.

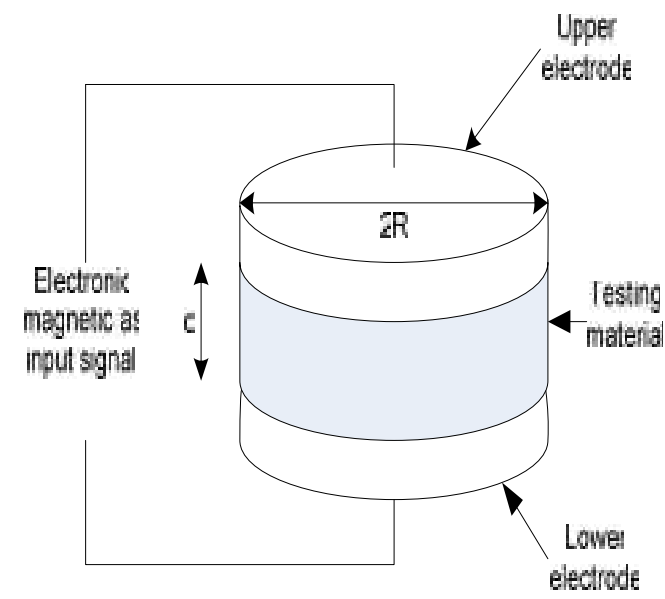

Gambar 1. Konfigurasi parallel plate
sample holder

Posisi kedua elektroda harus parallel satu sama lain dengan tujuan untuk menghasilkan medan listrik yang sesuai pada bahan sample sehingga diperoleh hasil yang akurat.

Konstanta dielektrik menggunakan parallel plate dapat dihitung dengan menggunakan parameter dimensi dari sample holder dan hasil pengukuran konduktansi dan kapasitansi dengan persamaan 2. Dari persamaan ini, komponen riil dan imajiner dapat dipisahkan seperti tampak pada persamaan 4 dan 5 .

$$
\begin{aligned}
\varepsilon^{\prime} & =\frac{C . t}{A . \varepsilon_{0}} \\
\varepsilon^{\prime \prime} & =\frac{G . t}{A \omega \varepsilon_{0}}
\end{aligned}
$$

Dimana:

$$
\begin{aligned}
& \varepsilon= \text { konstanta dielectric (permitivitas) } \\
& \varepsilon_{0}= \text { permitivitas ruang hampa yaitu } \\
& 8.85 \times 10^{-12} \\
& \varepsilon_{\mathrm{r}}= \text { konstanta relative dielectric } \\
& \text { (relative permittivity) dari test } \\
& \text { material } \\
& \mathrm{t}= \text { ketebalan of the testing material } \\
& \mathrm{A}=\text { luas penampang elektroda } \\
& \mathrm{C}=\text { kapasitansi terukur } \\
& \mathrm{G}=\text { konduktansi terukur }
\end{aligned}
$$


Parallel plate yang akan digunakan pada penelitian ini adalah Agilent 16451B Dielectric test fixture seperti tampak pada gambar 2 and 3 . Gambar ini memperlihatkan diagram cross-section dari sample holder dan konfigurasi elektrodanya.

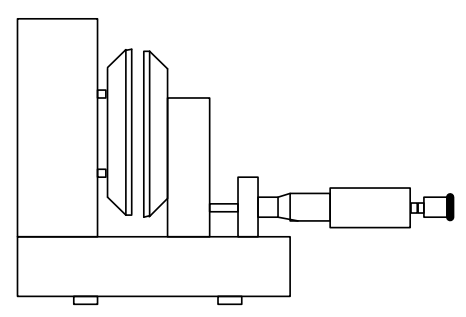

Gambar 2. Cross-section dari Agilent $16451 B$ dielectric test fixture

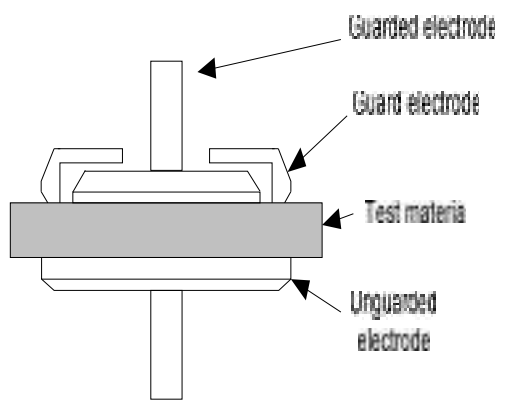

Gambar 3. Elektroda parallel plate untuk Agilent $16451 \mathrm{~B}$ dielectric test fixture

\section{METODE PENELITIAN}

\section{Survey teknik pengukuran dielektrik}

Pengukuran sifat-sifat dielektrik pada bahan-bahan yang mempunyai sifat dielektrik dapat dilakukan dengan berbagai teknik. Salah satunya menggunakan impedance analyzer. Pengukuran dielektrik yang akan dilakukan menggunakan HP impedance Analyzer dan sample holder. Impedance Analyzer digunakan untuk mengukur kapasitansi, kondukstansi dan admittansi dari sample bahan dan sample holder digunakan sebagai tempat untuk meletakkan sample bahan selama dilakukan proses pengukuran.

\section{Perancangan Sistem Dielektrik spektrometer}

Koneksi yang sederhana dalam pengukuran dengan menggunakan HP Impedance Analyzer dan sample holder disusun berdasarkan gambar 4. Bahan sample diletakkan pada sample holder dan dihubungkan ke HP impedance analyzer

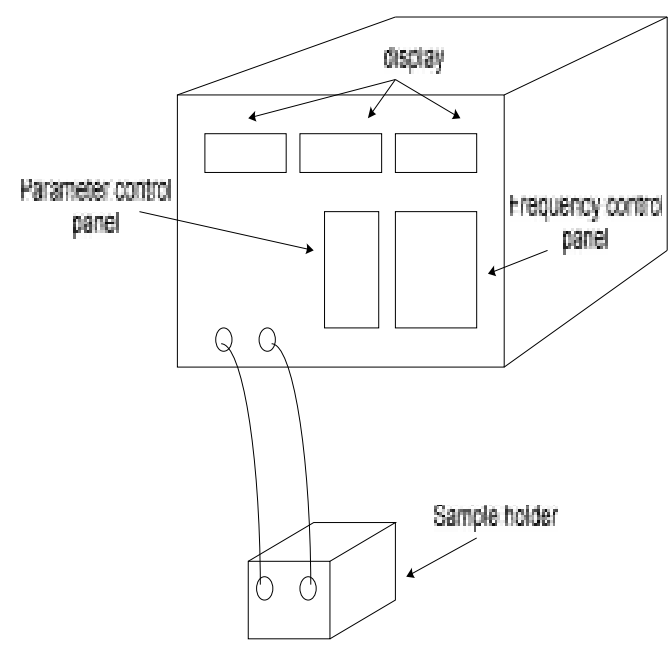

Gambar 4. Konfigurasi dari impedance analyzer dan sample holder

\section{Penentuan dan pengujian konfigurasi pengukuran}

Ada banyak konfigurasi sample holder yang dapat digunakan untuk pengukuran dielektrik. Namun pada penelitian ini akan mengggunakan konfigurasi parallel plate sebagai sample holder untuk material padat.

\section{Pengumpulan dan pengolahan data}

Pengukuran yang akan dilakukan pada penelitian adalah berupa data resistansi, impedansi, dan kapasitansi. Pengukuran ini juga untuk menentukan complex permittivity dari sample yang digunakan bersesuaian dengan masingmasing sample holder.

\section{Pengukuran Permitivitas Dielektrik}


Sample yang digunakan untuk pengukuran dengan menggunakan parallel plate adalah:

1. Sample 1 dan Sample 2 Lembaran tipis yang terbuat dari epoxy-based adhesive (Araldite 2015)

2. Sample 3

Lembaran tipis yang terbuat dari epoxy-based adhesive (Araldite 2011)

3. Sample 4

Kertas putih berbentuk bujursangkar dengan ukuran $3 \times 3$ $\mathrm{cm}$

Prosedur pengukuran menggunakan parallel plate

1. Menghidupkan Impedance Analyser HP4192A dan dibiarkan lebih kurang 45 menit untuk penstabilan hasil pengukuran.

2. Sample holder dielectric test fixture Agilen16451B dihubungkan dengan HP4192A.

3. Sample 1 diletakkan diantara dua elektroda yang ada pada test fixture.

4. Pengukuran nilai kapasitansi dan konduktansi dengan paralel plate dilakukan dengan memberikan frekuensi terendah $10 \mathrm{KHz}$ hingga frekuensi $13 \mathrm{MHz}$.

5. Sample berikutnya diukur nilai kapasitansi dan konduktansi dengan mengikuti langkah 1 sampai 4.

\section{HASIL DAN PEMBAHASAN}

\section{Hasil}

Seperti yang dijelaskan sebelumnya, sample material yang digunakan pada paralel plate sample holder adalah lembaran tipis yang terbuat dari epoxy-based adhesive (Araldite 2015) untuk sample 1 dan sample 2, -based adhesive (Araldite
2011) untuk sample 3 dan kertas untuk sample 4.

Hasil pengukuran menggunakan parallel plate dikalkulasikan untuk menentukan komponen permitivitas dari material yang digunakan pada penelitian. Bagian real e' dari permitivitas dihitung dengan menggunakan persamaan 4 dan persamaan 5 untuk bagian imajiner. Hasil dari kalkulasi kedua komponen permitivitas ini seperti tampak pada gambar 5 berikut ini.

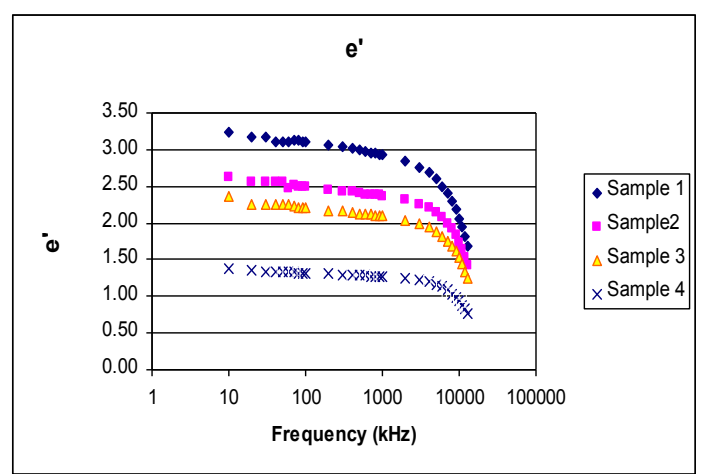

(a) Grafik bagian real e' dari permitivitas dan frekuensi

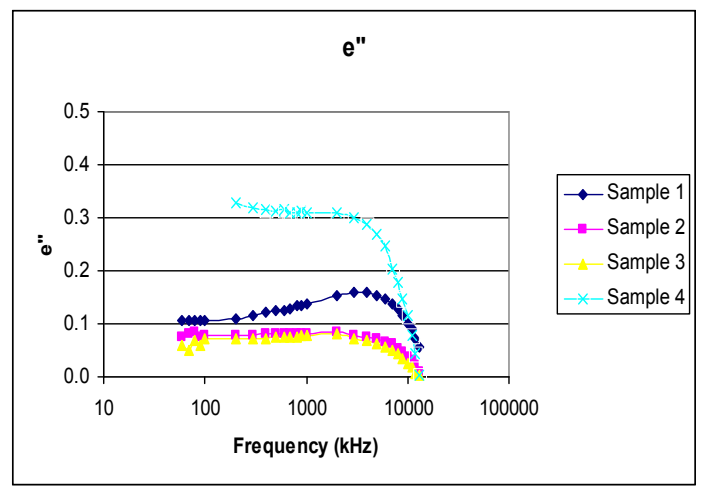

(b) Grafik bagian imajiner e" dari permitivitas dan frekuensi

Gambar 5. Grafik bagian real dan imajiner

\section{Pembahasan}

Gambar 5 (a) memperlihatkan bagian real dari permitivitas untuk sample 1 sampai 4. Pada frekuensi rendah nilai 
permitivitas relatif konstan, namun begitu frekuensi yang diberikan mendekati $8 \mathrm{MHz}$ nilai permitivitas ini meningkat tajam. Jika dilihat pada grafik, keempat sample pada paralel plate hampir memiliki sifat yang sama karena keempat sample memiliki struktur kimia yang hampir sama. Pada frekuensi yang sangat tinggi nilai permitivitas diharapkan mancapai nilai yang sama, namun hal ini sangat tidak memungkinkan mengingat keterbatasan frekuensi yang dimiliki oleh alat ukur yang digunakan.

Gambar 5 (b) memperlihatkan bagian imajiner dari permitivitas. Dari grafik dapat dilihat bahwa sample 4 mempunyai nilai e" sedikit lebih tinggi jika dibandingkan dengan sample 1 sampai 3, namun keempat grafik mengalami puncak dan selanjutnya mengalami penurunan nilai begitu mendekati frekuensi $10 \mathrm{MHz}$. Jadi dapat dikatakan bahwa bentuk grafik untuk keempat sample hampir sama karena semua sample memiliki karateristik yang mirip satu sama lainnya.

\section{KESIMPULAN}

Sample yang terbuat dari epoxybased adhesive (untuk sample 1-3) dan kertas untuk sample 4 memiliki bagian real permitivitas yang relatif konstan sampai frekuensi $8 \mathrm{MHz}$ dan mengalami peningkatan yang tajam untuk frekuensi yang lebih tinggi. Sedangkan untuk bagian imajiner, sample 4 memiliki nilai e" yang sedikit lebih tinggi dengan bentuk grafik yang mengalami puncak dan mengalami penurunan mendekati frekuensi $10 \mathrm{MHz}$.

Untuk meningkatkan range frekuensi maka hasil pengukuran ini dapat digunakan pada phenomenological relaxation model. Namun, ketepatan dari prediksi menggunakan pemodelan ini masih memerlukan study lebih lanjut.

\section{DAFTAR PUSTAKA}

Agilent - Basics of measuring the dielectric properties of material Application Note

G.Bindu, A.lonappan,V. Thomas, C.K.Aanandan and K.T.Mathew, 2006 "Dielectric studies of corn syrup for application in microwave breast imaging", PIER 59, 175-186.

N.G.McCrum, B.E.Read, G.Williams, 1967 "Anelastic and dielectric effects in polymeric solids", London: Willey.

A. Schönhals, "Dielectric Spectroscopy on the dynamics of amorphous polymeric systems", Novocontrol, Application Note Dielectric 1

J.Mijovic, B.D.Fitz, "Dielectric spectroscopy of reactive polymers", Novocontrol, Application Note Dielectrics 2

Raicu.V, 1995 "A simple theoretical and practical approach to measuring dielectric properties with an openended coaxial probe", United Kingdom, Measurement science technology, 410-414.

Jaspard.F and Nadi.M, 2002 "Dieletric properties of blood: an investigation of temperature dependence", Physiological Measurement 23, 547554.

Buff.P.Mark, Steer.Michael B, Lazzi.Gianluca, 2006 "Cole-cole dispersion models for aqueous gelatine-syrup dielectric composites", IEEE Transactions on 
geoscience and remote sensing, Vol. 44, No.2, 351- 353.

Shang, Jiyun, "Design and development of a LF dielectric spectrometer", University of Nottingham, Third year thesis, 2005

Patel, Sunit, 2003 "Simulation of the compression wave phase velocity of ultrasonic pulses transmitted through thermoset material during manufacture", University of Nottingham, Third year project thesis. 
ISSN : 2085-6989

\section{HALAMAN INI SENGAJA DIKOSONGKAN}

